\title{
Effects of GABA-Mimetic Drugs on Turnover of Histamine in the Mouse Brain
}

\author{
Masahiro NISHIBORI, Ryozo OISHI, Yoshinori ITOH \\ and Kiyomi SAEKI*
}

Department of Pharmacology, Okayama University Medical School.

2-5-1 Shikata-cho, Okayama 700, Japan

Accepted April 10, 1986

\begin{abstract}
The effect of GABA-mimetics on histaminergic activity in the mouse brain was investigated. Systemic administration of muscimol ( 2 and $5 \mathrm{mg} / \mathrm{kg}$ ), THIP (5-15 mg/ $/ \mathrm{kg})$ and aminooxyacetic acid (AOAA) $(25 \mathrm{mg} / \mathrm{kg})$ but not baclofen $(2.5-15 \mathrm{mg} / \mathrm{kg})$ inhibited the pargyline $(65 \mathrm{mg} / \mathrm{kg})$-induced accumulation of tele-methylhistamine $(\mathrm{t}-\mathrm{MH})$. There was no regional difference in the inhibitory effect of muscimol on the $\mathrm{t}-\mathrm{MH}$ accumulation by pargyline treatment. Muscimol and AOAA also inhibited decrease in the histamine (HA) level induced by $\alpha$ fluoromethylhistidine $(50 \mathrm{mg} / \mathrm{kg})$, a specific inhibitor of histidine decarboxylase. These results suggest that these GABA-mimetics reduce the HA turnover in the mouse brain.
\end{abstract}

Histaminergic (HAergic) neurons have been histochemically visualized in rats using antibodies against histidine decarboxylase (1) and histamine (HA) $(2,3)$. The cell bodies of HAergic neurons are present only in the posterior hypothalamic area, whereas the HAergic fibers occupy many areas of the brain in various densities $(1,3)$. Neurochemical studies of the turnover of HA in the brain provided data on the regional HAergic activity (4-6). The regulation of the activity of HAergic neurons by other neurotransmitters or neuromodulators has not been determined, although the $\mathrm{K}^{+}$-induced release of ${ }^{3} \mathrm{H}-\mathrm{HA}$ from slices of the rat cerebral cortex was reported to be under negative feedback control, through presynaptic autoreceptors (7).

$\gamma$-Aminobutyric acid (GABA) is an important inhibitory neurotransmitter in the mammalian central nervous system and GABAergic mechanisms are involved in the regulation of the activity of monoaminergic systems in some brain regions (8). Since GABA administered peripherally cannot penetrate the blood-brain barrier, several different

\footnotetext{
* To whom all correspondence should be addressed.
}

GABA-mimetics have been used in behavioral and neurochemical studies (9). We investigated the effects of an inhibitor of GABA transaminase (GABA-T), aminooxyacetic acid (AOAA), and GABA agonists such as muscimol, 4,5,6,7-tetrahydroisoxazolo-[5,4-c]pyridin-3-ol (THIP) and baclofen on the HA turnover in the mouse brain.

\section{Materials and Methods}

Animals and experimental procedure: Male ddY mice weighing 24-32 g (Shizuoka Laboratory Animal Center. Hamamatsu, Japan) were used. To examine the effect of the GABA-mimetics on the pargyline $(65 \mathrm{mg} /$ $\mathrm{kg}$, i.p.)-induced accumulation of telemethylhistamine (t-MH), AOAA $(25 \mathrm{mg} / \mathrm{kg}$, i.p.) was administered $90 \mathrm{~min}$ before pargyline treatment, whereas muscimol $(0.5-5.0 \mathrm{mg} /$ $\mathrm{kg})$, THIP (1-15 mg/ $\mathrm{kg}$ ) and baclofen (2.5$15 \mathrm{mg} / \mathrm{kg}$ ) were administered i.p. immediately before pargyline treatment. In these experiments, the mice were decapitated $120 \mathrm{~min}$ after pargyline treatment. When necessary, the brain was dissected into three brain regions: the telencephalon, hypothalamus, and brain stem (including thalamus). In the 
experiments on GABA-receptor antagonism, bicuculline and picrotoxin were given twice: i.p. at $10 \mathrm{~min}$ before and s.c. at $60 \mathrm{~min}$ after pargyline treatment. Bicuculline was first given in a dose of $2 \mathrm{mg} / \mathrm{kg}$ and then $1.5 \mathrm{mg} /$ $\mathrm{kg}$ was given. The first and the second doses of picrotoxin were 4 and $2 \mathrm{mg} / \mathrm{kg}$, respectively. The rate of disappearance of HA was determined after inhibition of histidine decarboxylase by $\alpha$-fluoromethylhistidine ( $\alpha$ $\mathrm{FMH})(50 \mathrm{mg} / \mathrm{kg}$, i.p.). The mice were decapitated $90 \mathrm{~min}$ after $\alpha-\mathrm{FMH}$ treatment. AOAA (25 mg/kg, i.p.) and muscimol (2 $\mathrm{mg} / \mathrm{kg}$, i.p.) were administered $90 \mathrm{~min}$ and immediately before $\alpha-F M H$ treatment, respectively.

Determination of $\mathrm{HA}$ and $\mathrm{t}-\mathrm{MH}$ : The $\mathrm{HA}$ and $\mathrm{t}-\mathrm{MH}$ contents in the brain, excluding cerebellum, were simultaneously determined using high performance liquid chromatography with fluorescence detection, as previously described (10). Statistical significance was evaluated by the two-tailed Student's $t$-test.

\section{Results}

Effect of GABA-mimetics on the pargylineinduced accumulation of $\mathrm{t}-\mathrm{MH}$ in the mouse brain: AOAA $(25 \mathrm{mg} / \mathrm{kg})$ and muscimol (1 and $2 \mathrm{mg} / \mathrm{kg}$ ) administered alone had no significant effect on either the HA or the $\mathrm{t}-\mathrm{MH}$ level in the mouse brain up to 4 and $2 \mathrm{hr}$ after injection, respectively. The turnover of $\mathrm{HA}$ in the brain was determined, based on the linear accumulation of $\mathrm{t}-\mathrm{MH}$, after pargyline treatment (4-6). As shown in Tables 1 and 2. pargyline increased the $\mathrm{t}-\mathrm{MH}$ level by about $110 \mathrm{ng} / \mathrm{g}$ during $2 \mathrm{hr}$ after injection, with no change in the HA level. The pargyline-induced accumulation of $\mathrm{t}-\mathrm{MH}$ in $\mathrm{AOAA}$-pretreated mice was as low as $35 \%$ of the control value in the saline-treated group (Table 1). Muscimol and THIP also significantly inhibited the pargyline-induced accumulation of $\mathrm{t}-\mathrm{MH}$ in a dose-dependent manner (Table 2 ). The intensities of the inhibitory effect of muscimol were not different among three brain regions: the telencephalon, hypothalamus and brain stem (Fig. 1). In contrast to the effects of muscimol and THIP, another class of GABA-receptor agonist baclofen (11) had no influence on the $\mathrm{t}-\mathrm{MH}$ accumulation by pargyline (Table 2). Systemic administration of bicuculline and picrotoxin failed to reverse the inhibitory effect of AOAA, muscimol $(2 \mathrm{mg} / \mathrm{kg})$ and THIP $(10 \mathrm{mg} / \mathrm{kg})$ on the pargyline-induced accumulation of t-MH (Table 3).

Effect of AOAA and muscimol on the $\boldsymbol{\alpha}$ $\mathrm{FMH}$-induced decrease in the $\mathrm{HA}$ level in the mouse brain: $\alpha-F M H ~(50 \mathrm{mg} / \mathrm{kg}$ ), a specific inhibitor of histidine decarboxylase, reduced the HA level to $45 \%$ of the initial level $90 \mathrm{~min}$ after administration. The treatment with either AOAA $(25 \mathrm{mg} / \mathrm{kg})$ or muscimol (2 $\mathrm{mg} / \mathrm{kg}$ ) significantly inhibited the decrease in the HA level induced by $\alpha$ FMH (Table 4).

\section{Discussion}

The turnover of $\mathrm{HA}$ in the brain was determined from the pargyline-induced linear accumulation of $\mathrm{t}-\mathrm{MH}$ (4-6), a predominant metabolite of HA in the brain $(12,13)$. The regional turnover rates of $\mathrm{HA}$ were demonstrated to have a good correlation with the steady-state t-MH levels (4-6); however, the reduction in the turnover of $\mathrm{HA}$ by the

Table 1. Effect of AOAA on HA and t-MH levels in the brain of pargyline-treated mice

\begin{tabular}{lll}
\hline Treatments & HA $(\mathrm{ng} / \mathrm{g})$ & $\mathrm{t}-\mathrm{MH}(\mathrm{ng} / \mathrm{g})$ \\
\hline Saline & $51.4 \pm 4.7$ & $120.5 \pm 12.5$ \\
AOAA & $46.2 \pm 3.4$ & $102.4 \pm 8.0$ \\
Saline+Pargyline & $46.6 \pm 4.1$ & $227.5 \pm 12.4^{*}$ \\
AOAA+Pargyline & $39.9 \pm 2.6$ & $140.3 \pm 11.9 \dagger$ \\
\hline
\end{tabular}

In the first and the second groups, AOAA $(25 \mathrm{mg} / \mathrm{kg}$, i.p.) or saline was administered 90 min before decapitation. In the lower two groups, pargyline $(65 \mathrm{mg} / \mathrm{kg}$, i.p.) was administered $90 \mathrm{~min}$ after AOAA (25 mg/kg, i.p.) or saline, and the mice were decapitated $120 \mathrm{~min}$ thereafter. The results are the means $\pm S$.E.M. of 6 or 7 animals. ${ }^{*} P<0.001$, as compared with the saline control group. $t P<0.001$ as compared with the saline+ pargyline group. 
Table 2. Effect of muscimol. THIP and (-)-baclofen on HA and t-MH levels in the brain of pargylinetreated mice

\begin{tabular}{lll}
\hline Treatments & $H A(\mathrm{ng} / \mathrm{g})$ & $\mathrm{t}-\mathrm{MH}(\mathrm{ng} / \mathrm{g})$ \\
Saline & $47.1 \pm 2.6$ & $118.5 \pm 7.4$ \\
Pargyline & $50.5 \pm 4.0$ & $226.4 \pm 7.9$ \\
Muscimol $(0.5 \mathrm{mg} / \mathrm{kg})+$ Pargyline & $48.0 \pm 1.5$ & $254.9 \pm 19.6$ \\
Muscimol $(1.0 \mathrm{mg} / \mathrm{kg})+$ Pargyline & $54.4 \pm 5.6$ & $205.9 \pm 17.7$ \\
Muscimol $(2.0 \mathrm{mg} / \mathrm{kg})+$ Pargyline & $49.5 \pm 3.6$ & $162.6 \pm 11.1^{* *}$ \\
Muscimol $(5.0 \mathrm{mg} / \mathrm{kg})+$ Pargyline & $50.8 \pm 1.6$ & $163.2 \pm 6.1^{* *}$ \\
Saline & $47.6 \pm 3.0$ & $116.7 \pm 4.0$ \\
Pargyline & $49.4 \pm 4.3$ & $231.7 \pm 10.1$ \\
THIP $(1 \mathrm{mg} / \mathrm{kg})+$ Pargyline & $51.9 \pm 4.5$ & $234.5 \pm 12.2$ \\
THIP $(5 \mathrm{mg} / \mathrm{kg})+$ Pargyline & $56.6 \pm 1.9$ & $200.9 \pm 12.4^{*}$ \\
THIP $(10 \mathrm{mg} / \mathrm{kg})+$ Pargyline & $56.9 \pm 2.5$ & $176.2 \pm 8.9^{* * *}$ \\
THIP $(15 \mathrm{mg} / \mathrm{kg})+$ Pargyline & $51.1 \pm 4.9$ & $178.3 \pm 12.4^{* * *}$ \\
Saline & $48.9 \pm 2.3$ & $88.1 \pm 7.5$ \\
Pargyline & $43.8 \pm 2.7$ & $213.6 \pm 6.1$ \\
(-)-Baclofen $(2.5 \mathrm{mg} / \mathrm{kg})+$ Pargyline & $47.9 \pm 4.3$ & $188.8 \pm 11.4$ \\
(-)-Baclofen $(5.0 \mathrm{mg} / \mathrm{kg})+$ Pargyline & $46.9 \pm 3.7$ & $217.0 \pm 12.3$ \\
(-)-Baclofen $(10 \mathrm{mg} / \mathrm{kg})+$ Pargyline & $43.8 \pm 2.3$ & $225.6 \pm 7.8$ \\
(-)-Baclofen $(15 \mathrm{mg} / \mathrm{kg})+$ Pargyline & $49.0 \pm 3.8$ & $224.0 \pm 20.5$ \\
\hline
\end{tabular}

Muscimol. THIP and (-)-baclofen were administered i.p. immediately before pargyline (65 mg/kg. i.p.) injection. Mice were decapitated $120 \mathrm{~min}$ after pargyline treatment. The results are the means \pm S.E.M. of 5 or 6 animals. ${ }^{*} \mathrm{P}<0.05,{ }^{*} \mathrm{P}<0.01,{ }^{* *} \mathrm{P}<0.001$ as compared with the corresponding pargyline group.

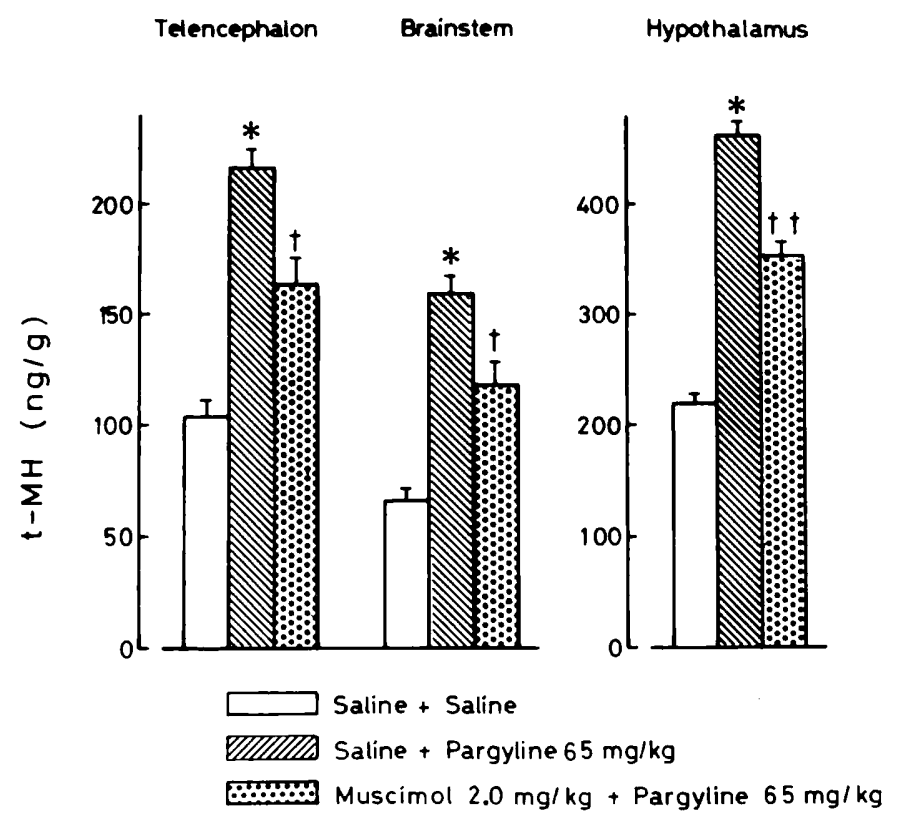

Fig. 1. Effect of muscimol on the pargyline-induced accumulation of $\mathrm{t}-\mathrm{MH}$ in different brain regions of the mouse. Muscimol (i.p.) was administered to mice immediately before pargyline treatment (i.p.). The mice were decapitated $120 \mathrm{~min}$ after pargyline. The results are the means \pm S.E.M. of $5-7$ animals. ${ }^{*} P<0.001$ as compared with the saline-saline group. $t P<0.05$, $t+P<0.01$ as compared with the salinepargyline group. 
Table 3. Effect of picrotoxin and bicuculline on the inhibition by AOAA, muscimol and THIP of t-MH accumulation

\begin{tabular}{|c|c|c|}
\hline Treatments & $\mathrm{t}-\mathrm{MH}(\mathrm{ng} / \mathrm{g})$ & $\Delta \mathrm{t}-\mathrm{MH}(\mathrm{ng} / \mathrm{g})$ \\
\hline Saline & $95.2 \pm 5.3$ & - \\
\hline Pargyline & $204.4 \pm 9.7^{*}$ & 109.2 \\
\hline Pargyline + AOAA & $167.3 \pm 7.3 t$ & 72.1 \\
\hline Pargyline + AOAA+Picrotoxin & $157.1 \pm 5.2 t \dagger$ & 61.9 \\
\hline Saline & $100.2 \pm 4.6$ & - \\
\hline Pargyline & $223.5 \pm 7.4^{*}$ & 123.3 \\
\hline Pargyline+Muscimol & $160.0 \pm 10.7^{* \dagger}$ & 59.8 \\
\hline Pargyline + Muscimol+Picrotoxin & $147.0 \pm 8.7^{t \dagger}$ & 46.8 \\
\hline Pargyline + Muscimol +Bicuculline & $166.7 \pm 4.7 \dagger \dagger$ & 66.5 \\
\hline Saline & $88.4 \pm 4.4$ & - \\
\hline Pargyline & $189.7 \pm 5.7^{*}$ & 101.3 \\
\hline Pargyline + THIP & $157.2 \pm 6.2^{\dagger \dagger}$ & 68.8 \\
\hline Pargyline + THIP + Picrotoxin & $158.3 \pm 5.9+t$ & 69.9 \\
\hline Pargyline + THIP + Bicuculline & $145.0 \pm 6.6 t \dagger$ & 56.6 \\
\hline
\end{tabular}

The doses of AOAA, muscimol and THIP were 25. 2 and $10 \mathrm{mg} / \mathrm{kg}$, i.p., respectively. Picrotoxin and bicuculline were given twice: $10 \mathrm{~min}$ before pargyline treatment $(65 \mathrm{mg} / \mathrm{kg}$, i.p.), i.p., 4 and $2 \mathrm{mg} / \mathrm{kg}$. respectively, and $60 \mathrm{~min}$ after, s.c., 2 and $1.5 \mathrm{mg} / \mathrm{kg}$, respectively. Other procedures were the same as in Tables 1 and 2 . The results are the means \pm S.E.M. of 5-10 animals. ${ }^{*} P<0.001$ as compared with the saline control group. $t P<0.05$, $t \dagger P<0.01$ as compared with the pargyline control group.

Table 4. Effect of AOAA and muscimol on $\alpha$-FMH-induced decrease in HA level

\begin{tabular}{rl}
\hline$-\ldots+-$ & $\mathrm{HA}(\mathrm{ng} / \mathrm{g})$ \\
Saline & $41.7 \pm 2.2$ \\
$\alpha$-FMH & $21.1 \pm 2.3^{* *}$ \\
AOAA $+\alpha-\mathrm{FMH}$ & $30.0 \pm 2.8^{*},{ }^{\dagger}$ \\
Muscimol $+\alpha-\mathrm{FMH}$ & $31.4 \pm 3.5^{*},{ }^{+}$ \\
\hline
\end{tabular}

AOAA $(25 \mathrm{mg} / \mathrm{kg}$, i.p.) and muscimol $(2.0 \mathrm{mg} / \mathrm{kg}$, i.p.) were administered $90 \mathrm{~min}$ and immediately before $\alpha-\mathrm{FMH}(50 \mathrm{mg} / \mathrm{kg}$, i.p.), respectively. The HA level was determined $90 \mathrm{~min}$ after $\alpha$-FMH treatment. The results are the means \pm S.E.M. of 6 or 7 animals. ${ }^{*} P<0.05$, ${ }^{*} P<0.01$ as compared with the saline group. $t \mathrm{P}<0.05$ as compared with the $\alpha-\mathrm{FMH}$ group.

drug is not sufficiently reflected in the $\mathrm{t}-\mathrm{MH}$ level as indicated previously (10). The present study also showed that AOAA and muscimol inhibit the pargyline-induced accumulation of $\mathrm{t}-\mathrm{MH}$ in the mouse brain in spite of the lack of influence on the steady-state levels of HA and $\mathrm{t}-\mathrm{MH}$. Another GABAA agonist THIP exerted the same effect, but the $G A B A B$ agonist baclofen was ineffective. These results suggest that muscimol. THIP and AOAA decrease the HA turnover in the mouse brain. This proposal is supported by the finding that treatment with either AOAA or muscimol significantly inhibited the reduction of HA after the treatment with $\alpha-F M H$, a specific inhibitor of histidine decarboxylase $(14,15)$. Thus, it is unlikely that the AOAA inhibition of the $\mathrm{t}-\mathrm{MH}$ accumulation is due, to an inhibition of the activity of histidine decarboxylase, an enzyme requiring pyridoxal phosphate as a cofactor. There was no difference in the intensities of the inhibitory effect of muscimol on the HA turnover among the three brain regions tested.

The doses of GABAA-agonist effective in decreasing the HA turnover in the present study were not high as compared with doses given in other studies $(16,17)$. This suggests that the inhibitory effects of these GABA agonists on the activity of HAergic neurons 
are mediated by GABAA receptors. However, the decreases in the HA turnover induced by muscimol, THIP and AOAA were not blocked by systemic administration of either bicuculline or picrotoxin. It has also been reported that the analgesic effects of muscimol and THIP are not antagonized by bicuculline $(18,19)$. Thus, the in vivo antagonism by bicuculline and picrotoxin of some effects of GABA-mimetics may be difficult to observe without inducing convulsions, as suggested by Murray et al. (19).

Recently. Takeda et al. (20) reported that in rats, most histidine decarboxylase-like immunoreactive cells in the caudal, tuberal and postmammillary caudal magnocellular nuclei of the posterior hypothalamus contain glutamate decarboxylase-like immunoreactivity and they suggested the possible coexistence of histamine and GABA. Thus, the regulation of $\mathrm{HAergic}$ neuronal activity by GABA-mimetics demonstrated in the present study may be relevant to the function of GABA synthesized in the HAergic neurons.

Acknowledgments: We thank Dr. J. Kollonitsch, Merck Sharp \& Dohme Research Laboratories, Rahway, NJ, U.S.A. and Dr. P. Krogsgaard-Larsen, The Royal Danish School of Pharmacy, Copenhagen. Denmark for generous gifts of $\alpha-\mathrm{FMH}$ and THIP. respectively.

\section{References}

1 Watanabe, T., Taguchi, Y., Shiosaka, S., Tanaka, J., Kubota, H., Terano, Y., Tohyama, M. and Wada, $H_{\text {.: }}$ Distribution of the histaminergic neuron system in the central nervous system of rats: a fluorescent immunohistochemical analysis with histidine decarboxylase as a marker. Brain Res. 295, 13-25 (1984)

2 Panula, P., Yang, H.-Y. T. and Costa, E.: Histamine-containing neurons in the rat hypothalamus. Proc. Natl. Acad. Sci. U.S.A. 81, 2572-2576 (1984)

3 Steinbusch, H.W.M. and Mulder, A.H.: Immunohistochemical localization of histamine in neurons and mast cells in the rat brain. In Handbook of Chemical Neuroanatomy, Edited by Björklund. A., Hökfelt, T. and Kuhar, M.J., Vol. 3, p. 126-140. Elsevier. Amsterdam (1984)

4 Hough, L.B., Khandelwal, J.K. and Green, J.P.: Histamine turnover in regions of rat brain. Brain Res. 291, 103-109 (1984)
5 Nishibori, M., Oishi, R. and Saeki, K.: Histamine turnover in the brain of different mammalian species: Implications for neuronal histamine half-life. J. Neurochem. 43, 1544-1549 (1984)

6 Oishi, R., Nishibori, M. and Saeki, K.: Regional differences in the turnover of neuronal histamine in the rat brain. Life Sci. 34, 691-699 (1984)

7 Arrang, J.-M., Garbarg, M. and Schwartz, J.-C.: Auto-inhibition of brain histamine release mediated by a novel class $\left(\mathrm{H}_{3}\right)$ of histamine receptor. Nature 302, 832-837 (1983)

8 Scatton, B., Zivkovic, B., Dedek, J., Lloyd, K.G., Constantinidis, J., Tissot, R. and Bartholini, G.: $\gamma$-Aminobutyric acid (GABA) receptor stimulation. III. Effect of progabide (SL 76002) on norepinephrine, dopamine and 5-hydroxytryptamine turnover in rat brain areas. J. Pharmacol. Exp. Ther. 220, 678-688 (1982)

9 Snodgrass, S.R.: Receptors for amino acid transmitters. In Handbook of Psychopharmacology, Edited by Iversen, L.L., Iversen, S.D. and Snyder, S.H., Vol. 17, p. 167-239. Plenum Press, New York (1983)

10 Oishi, R., Itoh, Y., Nishibori, M. and Saeki, K.: $j^{9}$-Tetrahydrocánnabinol decreases turnover of brain histamine. J. Pharmacol. Exp. Ther. 232, 513-518 (1985)

11 Bowery, N.G., Hill, D.R., Hudson, A.L., Doble, A., Middlemiss, D.N., Shaw, J. and Turnbull, M.: (-)Baclofen decreases neurotransmitter release in the mammalian CNS by an action at a novel GABA receptor. Nature 283, 92-94 (1980)

12 Schayer, R.W. and Reilly, M.A.: Formation and fate of histamine in rat and mouse brain. J. Pharmacol. Exp. Ther. 184, 33-40 (1973)

13 Schwartz, J.-C., Pollard, H., Bischoff, S., Rehault, J.C. and Verdiere, M.: Catabolism of ${ }^{3} \mathrm{H}$-histamine in the rat brain after intracisternal administration. Eur. J. Pharmacol. 16, 326-335 (1971)

14 Garbarg, M., Barbin, G., Rodergas, E. and Schwartz, J.-C.: Inhibition of histamine synthesis in brain by $\alpha$-fluoromethylhistidine, a new irreversible inhibitor: in vitro and in vivo studies. J. Neurochem. 35, 1045-1052 (1980)

15 Kollonitsch, J., Patchett, A.A., Marburg, S., Maycock, A.L., Perkins, L.M., Doldouras, G.A., Duggan, D.E. and Aster, S.D.: Selective inhibitors of biosynthesis of aminergic neurotransmitters. Nature 274, 906-908 (1978)

16 Kelly, P.A.T. and McCulloch, J.: Effects of the putative GABAergic agonists, muscimol and THIP, upon local cerebral glucose utilisation. J. Neurochem. 39, 613-624 (1982) 
17 Waszczak, B.L., Hruska, R.E. and Walters, J.R.: GABAergic actions of THIP in vivo and in vitro: A comparison with muscimol and GABA. Eur. J. Pharmacol. 65, 21-29 (1980)

18 Hill, R.C., Maurer, R., Buescher, H.-H. and Roemer, D.: Analgesic properties of the GABAmimetic THIP. Eur. J. Pharmacol. 69, 221-224 (1981)

19 Murray, T.F., McGill, W. and Cheney, D.L.: A comparison of the analgesic activities of 4.5,6.7 - tetrahydroisoxazolo [5,4-c]pyridin - 3 - of (THIP) and 6-chloro-2[1-piperazinyl]-pyrazine
(MK 212). Eur. J. Pharmacol. 90, 179-184 (1983)

20 Takeda, N., Inagaki, S., Shiosaka, S., Taguchi, Y., Oertel, W.H., Tohyama, M., Watanabe, T. and Wada, H.: Immunohistochemical evidence for the coexistence of histidine ciecarboxylase-like and glutamate decarboxylase-like immunoreactivities in nerve cells of the magnocellular nucleus of the posterior hypothalamus of rats. Proc. Natl. Acad. Sci. U.S.A. 81, 7647-7650 (1984) 